\title{
SEXUAL EDUCATION \\ IN THE ROMANIAN SCHOOLS \\ AFTER THE FALL OF COMMUNISM (1989)
}

ALIN ALBU*

Abstract: Introduced as an optional subject in 2004, "Sex education" aims to be stated as a compulsory subject, by implementing training programs in this regard and by developing of a secondary legislative frame. Unfortunately, besides some salutary themes, the curriculum contains several scientific and pedagogical errors regarding sexuality, it does not present honestly the negative effects of the contraceptive measures, and it ignores certain mechanisms of the adolescent psychology. The fact that the Romanian initiative is closely related to some resolutions of the European space which promote sexual education in schools, the fact that the organizations that support the rights of sexual minorities are lobbying for the introduction of the subject as mandatory and that among the authors and the trainers of this project there are apologists of sexual deviances and vehement objectors to religion as a school subject, all these show that there are several factors concerned and the stake is much higher than at it appears: this discipline is intended as a doctrine of early sexualization of the children, of sexual liberalization.

Keywords: Sexual Education/Health Education, sexual minorities, human rights, School, Family.

After the fall of communism in Romania (1989), the sexual message gradually reached the collective consciousness through the media, so that today it has become a fact of life everywhere: in advertisements, radio and TV shows, movies, newspapers, posters, websites etc. The most vulnerable are the children who, being daily besieged, will incline to early sexual manifestation or to deviant sexual behavior. Unfortunately, in the last decade there have been efforts to introduce this message in the Romanian school through the subject called "Health Education" (sexual education). The reason: to avoid the cases which have occurred lately, namely teen pregnancy,

\footnotetext{
${ }^{*} \mathrm{PhD}$, Reverend, Assistant Proffesor at the Faculty of Orthodox Theology of "1 Decembrie 1918" University in Alba Iulia, Romania. He teaches History of Romanian Orthodox Church.
} 
HIV infections, etc. This is how they argue in favour of this: "Romania has one of the highest rates of maternal mortality in Europe, where a large share of it is represented by maternal deaths after abortions. In this context the importance of unintended pregnancies should be emphasized, otherwise entirely avoidable (!!!) (our emphasis) using modern contraceptive methods" ${ }^{1}$.

The project was conducted in 2002-2003 and approved in 2004, when the subject "Health Education" became effective as an optional subject. But the curriculum shocked by presenting to very young children premature sexual themes and also by the presentation of sexual deviances as being normal (detailed in Multimedia Kit recommended by the Education Ministry as teaching material and course support). Modified due to the appeals, the curriculum approved in 2004 left space for ambiguities and criticism anyway. In addition to the positive topics (hygiene, nutrition, relaxation, etc.), for the first and second grades there are also some improper subjects and topics such as: preventing HIV / AIDS, drugs (children are only 6-8 years old!), nudity (the children are familiarized with nudity by showing them drawings of nude boys and girls in various stages of sexual development). Similarly, in the curriculum for the III-VIII grades, in addition to the topics related to pollution, vocation training, first aid, human trafficking etc., there are also topics that are more premature: attitudes towards sexual life debut, contraception, unwanted pregnancies and abortion. There are also added "useful addresses", which are, in fact, abortion and family planning clinics.

Over the last few years there have been pressures in order to make this school subject compulsory. Since December 2010, the Ministry of Education approved the implementation of some training programs in this regard and the "development of the legislative side." The multimedia CD entitled "Love and Sex - Truth and challenge", designed by sexologist Dr. Cristian Andrei (certified as a trainer of

\footnotetext{
${ }^{1}$ The national program "Education for health in the Romanian school", program conducted under the patronage of Adrian Năstase, Prime Minister of the Romanian Government, p. 3; http://media.tvrinfo.ro/other/201203/programeducatie-sanatate_95171600.pdf.
} 


\section{$15^{\text {th }}$ International Symposium on Science, Theology and Arts}

trainers in this program) has been promoted, which is a kit that lists various perversions and includes the chapter "What are you?", a material provided (Nota Bene!) by the Foundation of the Homosexuals in Romania - "Accept"2. Together with dr. Cristian Andrei, the "specialists" team consists of the psychologist Aurora Liiceanu and the journalist MirceaToma. Aurora Liiceanu is an ardent supporter of the contraceptive pill, which she considers "a tremendous innovation that allows woman to be the sovereign of her own body", and she is the author of the national program "My life is a serious game" which has become optional subject in secondary schools and it provides students notions of masturbation or about the right age to begin their sexual life - parents being advised to stop teaching their children the principle of abstinence. It also provides information about contraceptive services, sexual orientation and abortion (at the secondary school level!).

As for the journalist MirceaToma, also a "specialist" of the national sexual education program, his moral probity was strongly shaken by the imminence of the termination of his parental rights, as he was caught in 2009 together with his pregnant wife on a nudists' beach in VamaVeche, in front of their minor daughter. He participated in lesbian and gay marches also accompanied by his wife, being a "commissioner" of "political correctness" in the Romanian press $^{3}$. Is interesting to note that MirceaToma is also one of the militants for removing / replacing religion in schools, being among the signatories of the petition for the withdrawal of religious symbols in public schools: "the effect of the Orthodox icons on the

\footnotetext{
${ }^{2}$ http://ro.scribd.com/doc/94185355/EDUCA\%C5\%A2IA-SEXUAL\%C4\%82. ${ }^{3} \mathrm{http}: / /$ roncea.ro/2011/09/19/rosia-montana-si-salvatorii-ei-mircea-toma-siliviu-mihaiu-salarii-de-milioane-de-euro-capcanate-cu-ajutorul-idiotilor-utilicare-lupta-pentru-ecologie-si-patrimoniul-national/;

http://www.danbadea.net/2014/01/24/sobolanul-voiculescu-si-puricii-crescutiin-blana-lui-ce-au-transmis-ciuma-bubonica-in-presa-romaneasca/;

http://roncea.ro/2011/08/14/fan-fest-in-delir-fotografie-exclusiva-de-la-fatalocului-cu-george-soros-mircea-toma-si-renate-weber-salvatorii-rosieimontane/; http://roncea.ro/2011/09/02/cianura-ucide-dar-si-prostia-ucideromania-societatea-civila-bolsevica-si-apologetii-crestini/.
} 
walls is similar to that of an advertisement for a soft drink hanging on the walls of the school all day" $(2006)^{4}$.

These "experts" of the Ministry of Education are, behold, those in charge of training teachers and inspectors. Thus, in the spring of 2011, the Ministry organized training courses in "Education for Health", teachers being trained on the importance of contraceptive use by children. Here is what, prof. Daniela Călugăru, the project coordinator, general inspector of the Ministry of Education, says in an interview: "The local community has become more open to introducing this discipline in school lately. And we have received positive feedback from the students, they want that Health Education to become a compulsory subject" ${ }^{5}$. We do not know on what surveys these allegations are based, or whether completed studies on the impact of this program have been made and what category of students have sent the "positive feedback" mentioned in the interview.

In these circumstances, there were intentions of some politicians to force the introduction of this subject as compulsory, for instance the bill from April 2011 ${ }^{6}$. The infrastructure is in preparation, legislative steps have been made, so that things are advanced! The Metropolitan of Cluj, BartolomeuAnania, said on Christmas in 2010 that "is inadmissible to swear with your hand on the Bible and make laws against the Bible,"referring to lawmakers voting laws for prostitution, pornography, homosexuality, concubinage, practices that are open paths for the disintegration of

\footnotetext{
${ }^{4}$ http://roncea.ro/2011/09/02/cianura-ucide-dar-si-prostia-ucide-romaniasocietatea-civila-bolsevica-si-apologetii-crestini/.

$5_{* * *}$ In ţara fetiţelor mame, educaţia sexuală e un tabu, in „Evenimentul zilei”, January 19th 2011.

${ }^{6}$ In April 2011, the deputy Tudor Ciohodariu ellaborated a project in this respect. After presenting the reasons he mentioned that the impact of the program had already been demonstrated in other states! The Chamber of Deputies approved it, but the Senate did not. The negative point of view of the government invoked two reasons: 1. the Ministry of Education and Research had already considered a new curriculum for this discipline; 2 . there are no funds!

http://www.cdep.ro/proiecte/2011/100/10/8/em118.pdf; http://www.cdep.ro/proiecte/2011/100/10/8/pvg118.pdf.
} 


\section{$15^{\text {th }}$ International Symposium on Science, Theology and Arts}

the family and the dissolution of society. "We have an anti-drug law, but no law against debauchery; we have a law against corruption, but no law against seduction!!!"7.

\section{International legal framework: $\mathrm{UN}$ and $\mathrm{EU}$ resolutions}

In 1976, the Equal Treatment Directive (ETD) was issued, which required the principle of equal treatment for men and women in access to employment, vocational training and promotion, and working conditions. The Paper of Fundamental Rights in December 2000 made the principle of non-discrimination (religious, social class, gender, sexual orientation, etc.), one of the ideological pillars of the European construction. In a document of the European Commission in 2004 entitled "Green Paper. Equality and nondiscrimination in an enlarged European Union", which was meant to be a platform for future law developments, equal treatment and nondiscrimination are considered the cornerstone of the European Union foundation.

Some European resolutions (for example, two reports of the Parliamentary Assembly of the Council of Europe in January 2010) attempt to impose a legislation obliging the European countries to accept and promote sexual education in schools, abortion as a "human right" and homosexuality as a normal expression of sexual orientation: in February 2010 the European Parliament adopted a resolution on the integration of Croatia, Macedonia and Turkey in the European Union, by stating that granting rights to the community of gay, lesbian, bisexual and transgender (LGBT) is an essential condition for the accession! ${ }^{8}$; there is a National Council for Combating Discrimination in every EU country, directly coordinated by the European Commission, and not by the Government of that country, having the task of implementing the law on discrimination.

\footnotetext{
${ }^{7}$ Metropolitan Bartolomeu Anania, Pastoral letter on the Nativity of the Lord, 2010.

${ }^{8}$ http://pettycluj.blogspot.ro/2010/07/credinta-tarilor-candidate-ue-darcare.html.
} 
Alongside these councils, NGOs networks and foundations financed by the Union are heavily lobbying in this regard. We must also mention the recent discussions about accepting the civil partnership (the civil rights of homosexual couples).

In June 2009, UNESCO, as an UN agency, gave the public a document drawing the plan for the worldwide implementation of sexual education for young people between 5 and 18 with the objective of combating HIV / AIDS. As it openly supports onanism, and sexual license in adolescents and it presents homosexual couples as an alternative to the traditional family, the document caused protests worldwide, which has led the UNESCO ideologists to a reassessment (the report initially established that the children between 5 and 8 should learn about masturbation, at 9 years about aphrodisiacs, at 12 years about the motivation of abortion and at 15 on the right and access to legal abortion ${ }^{9}$ ). Inadmissible boundaries of innocence were forced, sexual education being introduced to primary school! Although disguised, the new report from September 2010 unfortunately contains the same educational guiding principles. More serious is the fact that these principles are the reflex of the educational philosophy of the Kinsey Institute in the US, founded by one of the most famous sexologists, Alfred Kinsey, very controversial today because he has based his researches and statistics on the information provided by pedophiles. Among others, Alfred Kinsey claimed that children are sexual beings and they need to be stimulated in this direction and he categorized some sexual deviations as normal. So, one can see that today some of the UNESCO principles regarding sexual education are based on Kinsey's philosophy, one of the biggest detractors of morality in the $\mathrm{XX}$ century.

In 2009, Romania received warnings from the UN on the grounds that it had not done enough to implement certain rights of the child, recommending our country to introduce sexual education classes and also to offer confidential health sexual services and

\footnotetext{
${ }^{9} \mathrm{http}: / /$ saccsiv.wordpress.com/2009/08/27/indemn-unesco-copiii-vor-invatadespre-masturbare-la-5-ani-si-despre-avort-la-12-ani/.
} 


\section{$15^{\text {th }}$ International Symposium on Science, Theology and Arts}

contraceptive methods and free or low-cost services of family planning, depending on the type of person.

Finally, the ECHR (European Court of Human Rights) has become a part of this trend, issuing contradictory decisions, even discriminatory (see the cases in 2009: the court decided in favor of an Italian citizen who had felt offended and discriminated by crucifixes inclassrooms where his child had been studying and demanded the withdrawal of crucifixes from all public schools in the Italian state. In another case, however, the German family sued the state because their paternal rights were violated, by forcing their children to attend sexual education courses that their parents considered anti-Christian, the ECHR ruled in favor of the state against the citizen). In both cases were invoked freedom of conscience and the right of the parents to educate their children in the spirit of their own religious beliefs!

The initiators of this project in Romania invoked the success of the program in countries that have established such education, but dishonestly omitting studies and statistics that show just the opposite.

For example, in the United Kingdom - although sexual education in schools is compulsory, despite the parents' choice that are $79 \%$ against such courses, the country holds the first place in Europe at the rate of teenage pregnancy; there, prof. John Jemmot shows in a study that over $50 \%$ of children who attend sexual education begin their sexual life at an earlier age than those who are taught abstinence. The researcher concluded: "it would be more efficient to encourage children to be abstinent than to teach them about contraception"10.

$10 \mathrm{http}: / / \mathrm{www}$. libertatea.ro/detalii/articol/copiii-care-primesc-educatie-sexualaisi-pierd-virginitatea-mai-devreme-274805.html. Other negative examples from this area: the film "Living and Growing", produced for the sexual education of children of 8 in British primary schools containing explicit sex scenes in a couple, was expanded to 3,400 schools (approx. 1 million children), although parents protested against it, because it promoted early sexuality, birth control, homosexuality and abortion (remember, children of 8!!!); http://saccsiv.wordpress.com/category/sex-oral/Filmul "Living and Growing" elevilor de 8 ani din scolile britanice. In 2009, the British National Health 
Spain - In 2009 the Spanish government launched a program entitled "Discover masturbation" to inform young people who are 1417 years old, which had the slogan "Pleasure is in your hands", a program that stirred many disputes up to the declaration of a politician who said that the initiative "puts Spain to shame"11. Here, the government led by socialists imposed mandatory sexual education classes where homosexuality is presented as a normal sexual behavior.

Sweden - the country with one of the highest percentage of venereal diseases in Europe, and an increasing number of pregnancies in girls of 12-13; the officialities declare that sex education took it the wrong way.

French say that they have failed the process of sexual guidance, mainly because it has been made by incompetent persons ${ }^{12}$.

Latin America - during the classes of sexual education teachers organized short sketches in which children of 10-12 years virtually simulate sexual acts. There are countless negative examples and the so-called positive experiences of those countries who encouraged sexual education in young classes, experiences invoked by Romanian initiators of this project, are refuted in many cases. Worse is that these failures are notorious and yet ignored by Romanians and they rely on the Western practice.

\section{*}

After this historical and legal approach, a psychological, medical, educational, social and theological assessment of some contents of the Romanian curriculum is required. A critical study

Service initiated a campaign among students about the right to a sex life just like the adults' on the condition to be properlyinformed, and how regular intercourse or onanism could prevent some diseases; http://www.hotnews.ro/stiri-international-5952156-elevii-din-marea-britaniesunt-indemnati-aiba-orgasm.htm.

${ }^{11} \mathrm{http}$ ://saccsiv.wordpress.com/2009/11/18/campanie-pro-masturbare-in-spaniaplacerea-sta-in-mainile-tale/.

${ }^{12} \mathrm{http}$ ///invataturicrestine1.blogspot.ro/2012/10/pericolele-modului-de-educatiesexuala.html. 


\section{$15^{\text {th }}$ International Symposium on Science, Theology and Arts}

signed by specialists in different fields (teachers, social workers, lawyers, sociologists, psychologists, doctors etc.) signalled several scientific and pedagogical errors.

For instance, disregarding the fact that psycho-physical maturation is not uniform and simultaneous in adolescents, this syllabus presents dangerous generalizations that could induce young people who do not fit the pattern, the respective description, the idea that something is wrong with them, or, conversely, they are presented as normal or even some particular aspects of deviant sexual behavior $^{13}$. Such impersonal sexual education will inevitably lead to a traumatic leveling of such a personal area of human experience.

Then, the negative biological and psychological consequences of some sexual issues and practices are not presented, as they were demonstrated by medicine and psychology, or there is inaccurate information about the adverse health effects posed by various contraceptive measures, especially in the case of abortion: physical health consequences (up to sterilization and even death) and mental health (post-abortion syndrome - depression, psychosis, even schizophrenic reactions, suicide). Despite that over the past few years girls of 14 or even younger have come to the gynecological surgeries for abortion and Romania is among the countries with the highest rate of abortions (see the report of doctor Christa Todea Gross from Cluj, serving in the "Christiana" Philanthropic Association). They do not say in all these educational materials that currently used contraceptives are abortifacients, contragestive! They do not say that the pill has been called "slow suicide", that result of the contraception during several years means "a sick body"! They do not say these things, even if the majority of the school girls who have started their sexual life are taking the pill.

\footnotetext{
${ }^{13}$ For ex., generalizations like "over $90 \%$ of men have masturbated at least once"; " $25 \%$ of men have practiced anal sex at least once" etc. "Over $90 \%$ and $25 \%$ " of what men? Of those included in the investigation, of course! From what investigation? From the one made in the US and some Western countries, where Romanian sexual educators extracted information, but not from those existing in our country, where until now there has been another conduct in this direction!
} 
In the related multimedia kit "Health Education Program" homosexuality falls within normality (one chapter is entitled Normal Sexual Behavior: Heterosexuality. Homosexuality. Bisexuality) and gay marriage legalization in some states is labeled as an "assured success" (in February 2012 The Association "Accept" came out in public to promote gay rights and the authorities approved the access of this association in educational institutions, even among minor children). This, despite the fact that its framing is contrary to the Criminal Code Article 201 which calls homosexuality "unnatural act in connection with the sexual life", and that the textbooks of medical, psychology, psychiatry, clinical psychology, psychiatric ethics, range it as a perversion of the sexual instinct, as a deviation, a vice.

In addition to homosexuality, there are portrayed types of sexual behavior disavowed by the moral norms, such as autoeroticism. Instead of being considered an indecent vice, autoeroticism is considered harmless, if not beneficial. This, contrary to the practice of medicine which shows that autoeroticism can determine overstress, insomnia, irritability, isolation, apathy, disordered memory and judgment, loss of appetite, headache, fatigue for a child, and for pubescent and teenager, neurotic syndrome, impotence, predisposing to isolation, melancholy, inclination to hypochondria.

Moral imbalance occurs, therefore, also in the psychosomatic plan: big losses of vital energy produced by the debauchery drain the life out of the young people, destroying nerve cells and destabilizing the endocrine system; the sinful imagination comes to tyrannize, to create a deep unease, to trigger a state of anxiety and aggression, which can degenerate into slavery and sexual perversion.

Neither from a pedagogical perspective, does sexual education, as it is conceived in these programs, bring any benefits, but only prejudices: the presentation of the intimate, delicate sexual aspects without the foundation of love and outside the context of one's own feelings, risks to bring into the inner universe of young people not the information and training but aggressive and vulgar instincts, adding the danger of minimalisation and the lack of inhibition, leading to mental and behavioral mutations: "Sexual 


\section{$15^{\text {th }}$ International Symposium on Science, Theology and Arts}

education is an intention of cleansing love, leading to the emotional sterilization"14. Is it scientific or appropriate to give the latest information on sexual activity in a material considered educational to which should be added also the list of the products available in a sex shop? (See section "Particular aspects of sexual behavior"). Certainly, the pedagogical impact will be rather negative, so the discipline is a brutal method of introduction to sexuality. Then, ignoring certain mechanisms of the adolescent psychology, educators do not consider a possibility: instead of informing, they stimulate and amplify the desire and curiosity of young people who may be tempted to experiment what they find in the materials for sexual education - this is similar to the principle of advertising and marketing that targets increasing the consuming and sale: the systematic repetition of information to stimulate the potential client.

Moreover, from the social point of view, there is a mental pressure on the teenager in order to achieve a certain type of attitude, which must confirm the dominant impression related to certain expectations of the group.

From a spiritual perspective, sexual education in schools and family planning, which triggers rather than educates the sexual instinct at an adolescent age, lead to the sin of lust, which is "the existential failure of youth": depersonalizing love, making the teenager in a "partner-object" for the others, altering chastity and dignity, killing great ideals, desolating personal life that becomes a commonplace, disordered and "worn-out" (Rev. Fr. Ilie Moldovan).

Such an education based on knowledge of anatomy, physiology and hygiene - and not entirely scientifically supported -, without moral guidelines and without offering the psychological support to the developing personality of adolescents, is a disabled education, which instead of making the young people more informed and less complex and lacking inhibitions - as desired - creates a generation of young exhibitionists who "will become a great burden, not a support when we are old" (dr. Christa Todea-Gross)!

\footnotetext{
${ }^{14}$ Marius Iordăchioaia, Iubire fără milă, in „Orthograffiti”, March 9th 2012.
} 
Such an education could become a doctrine of early sexualization of children, which, instead of cultivating, incites to "anarchosexuality" (sexual liberalization). It is actually a vicious circle that, trying to reduce sexually transmitted diseases in young people, unwanted pregnancies and abortions, actually encourages early sexual contact and the use of contraceptive methods, which involves health risks and increases the prevalence of diseases and abortions!

Could this education be the reflex of new paradigms, new conceptions of sexuality, where the sin of debauchery is considered emancipation (so that the adolescent is not repudiated by the group, as bigot and anachronistic), abortion is elevated to the status of "human law" and the traditional family is in competition with the homosexual family and "surrogate mothers"? The new guidelines, so-called "modernist", "civilized", which lobby for abortion, contraception, homosexuality, want to impose a new vision, a "reeducation" in which Christian principles to be replaced with expressions - because they cannot be called values - of sexual libertinism.

This "new vision of youth" and sexuality, this permissive mentality intends to "unleash" the young people from the "religious and moral barriers", the traditional educational model, which hitherto gave clear axiomatic landmarks in the family (Rev. Fr. Ilie Moldovan). Furthermore, gradually diluting the degree of permissiveness of society itself, one goes from immorality to perversion ("if small children learn to sin, then they will not consider anything a sin," His Grace, Bishop Gherasim Putneanul). Consequently, the sin of lust becomes a norm of life, divorce and abortion become the new social customs and the sense of responsibility, so necessary for the future of a young family will fade. "The sought-after liberatio", the desire for emancipation from the paternal authority, actually prove to be a cruel form of moral slavery, a repetition of the painful experience, the spiritual drama of the prodigal son. 
In these circumstances, approaching the topic of sexuality in front of young people is a big challenge from a spiritual point of view and it requires judgment and tact. Paternal and fraternal, delicate and prudent, but without coddling in a damaging way the conscience of the interlocutor, the biological parent, the priest, the teacher, the psychologist, the physician should assume the responsibility of a recovering pedagogy towards the adolescent exposed to a sexuality out which the postmodernism retains only the biological.

Denouncing the reductionist concept that adolescence should be a simple biological phase, the authentic educator must define it as an essential moment of self-knowledge, of developing spiritual maturity, of acquiring new abilities and behaviors. Above all, the family and the Church are those who are meant to teach children true love, the key to the harmonious psychological and spiritual development of the future adult (Hieromonk ArseniePapacioc), the mystery of pure love and creation - against contraception and abortion. Only by understanding the miracle of love, as a "gift of God... and not simple animal biology" (Rev. Fr. Ilie Moldovan), will the young person distinguish pure love from fake love, they will surpass themselves in this aphrodisiac culture living the wonderful and virtuous beauty of youth age. Fighting for pure love, for preserving their virginity and purity of heart, the young people will actually fight for their own inner freedom.

The urge to true manhood, to the heroism of virtue can only come from educators aware of their role in the spiritual regeneration of a society in which eroticism exacerbation opens multiple ways for the family disintegration and dissolution of the moral values. The church has, in this case, the privilege, especially the vocation ("the call" - as mission!) "for a true education of love"15. For love is preserved and increases not by sex, but by holiness!

\footnotetext{
${ }^{15}$ Marius Iordăchioaia, Iubire fără milă, in „Orthograffiti”, March 9th 2012.
} 


\section{Conclusions}

During the two and a half decades after the Revolution, major changes have occured in the Romanian collective consciousness on the subject of sexuality. If in the $90 \mathrm{~s}$ it was inconceivable for an incondite program of "Sexual Education" to be implemented in schools in a majoritary Orthodox country, now there are few who accept the challenge of minimizing negative consequences. If sexual education has become a subject, now the religion classes in school disturb some!

Introduced as an optional subject in 2004 , over the past few years, not by chance amid opposition from some people who are against the religion class, "Sex education" aims to be stated as a compulsory subject, by implementing training programs in this regard and by developing of a secondary legislative frame.

Unfortunately, besides some salutary themes of hygiene, nutrition, etc., the curriculum contains several scientific and pedagogical errors regarding sexuality, it does not present the negative effects of the contraceptive measures on the biological and psychological health honestly, it ignores certain mechanisms of the adolescent psychology, being "a brutal method of introduction to sexuality".

The fact that the Romanian initiative is not isolated, but closely related to some resolutions of the European space which promote sexual education in schools, the fact that the organizations that support the rights of sexual minorities are lobbying for the introduction of the subject as mandatory and that among the authors of the support materials (textbooks) and the trainers of this project include apologists of sexual deviances and vehement objectors to religion as a school subject, all these show that there are several factors concerned and the stake is much higher than at it appears: this discipline is intended as a doctrine of early sexualization of the children, designed to ensure in the future generations the success of the new anthropological paradigms, of sexual liberalization, in which lust is considered emancipation, abortion is considered "human right" and the traditional family competes with the homosexual family. 
Orthodoxy is in favour of equality and non-discrimination, as there is no other religion (Galatians 3:28), it is in favour of the human freedom and of natural rights, but not in favourof perversion. Therefore, balancing this situation is the task of the Church and of the family, not just of educators and specialists, they all need to promote an authentic education of love that will know how to relate naturally to sexuality.

\section{References}

- Albu, Alin, Sexual education in schools - lecture during the national conference "Valentine's Day - celebration of love. Contemporary challenges of sexuality", Faculty of Orthodox Theology Alba Iulia, February 28th 2013 (in press).

- Albu, Alin, Prefață la Ilie Moldovan, Adolescența, preludiu la poemul iubirii curate, Alba Iulia, Reîntregirea, 2016(in press).

- Albu, Alin, Probleme etice, psihologice și legale ale sexualității în lumea contemporană, in „Îndrumător Pastoral” 2015, Alba Iulia, Reîntregirea, 2015.

- ÎPS Anania, Bartolomeu, Pastorală la naștereaDomnului, ClujNapoca, 2010.

- „Educația pentru sănătate” în școală - un pericol pentru moralitatea copiilor noștri, Constanța, Fundația și Editura „Sfinții Martiri Brâncoveni”, 2012.

- Iordăchioaia, Marius, Iubire fără milă, in „Orthograffiti”, March 9th 2012.

- *** In țara fetiţelor mame, educaţia sexuală e un tabu, in „Evenimentul zilei”, January 19th 2011.

- Moldovan, Ilie, Adolescența, preludiu la poemul iubirii curate, Alba Iulia, Reîntregirea, 2014.

\section{Web sources}

- http://media.tvrinfo.ro/other/201203/program-educatiesanatate_95171600.pdf

- http://ro.scribd.com/doc/94185355/EDUCA\%C5\%A2IASEXUAL\%C4\%82 
- http://roncea.ro/2011/09/19/rosia-montana-si-salvatorii-ei-mirceatoma-si-liviu-mihaiu-salarii-de-milioane-de-euro-capcanate-cuajutorul-idiotilor-utili-care-lupta-pentru-ecologie-si-patrimoniulnational/

- $\quad$ http://www.danbadea.net/2014/01/24/sobolanul-voiculescu-si-puriciicrescuti-in-blana-lui-ce-au-transmis-ciuma-bubonica-in-presaromaneasca/

- http://roncea.ro/2011/08/14/fan-fest-in-delir-fotografie-exclusiva-dela-fata-locului-cu-george-soros-mircea-toma-si-renate-webersalvatorii-rosiei-montane/

- http://roncea.ro/2011/09/02/cianura-ucide-dar-si-prostia-ucideromania-societatea-civila-bolsevica-si-apologetii-crestini/

- http://www.cdep.ro/proiecte/2011/100/10/8/em118.pdf

- http://www.cdep.ro/proiecte/2011/100/10/8/pvg118.pdf

- http://pettycluj.blogspot.ro/2010/07/credinta-tarilor-candidate-ue-darcare.html

- http://saccsiv.wordpress.com/2009/08/27/indemn-unesco-copiii-vorinvata-despre-masturbare-la-5-ani-si-despre-avort-la-12-ani/

- http://www.libertatea.ro/detalii/articol/copiii-care-primesc-educatiesexuala-isi-pierd-virginitatea-mai-devreme-274805.html

- http://saccsiv.wordpress.com/category/sex-oral/Filmul "Living and Growing" promoveazadesfranarea, perversiunile, homosexualitateasianticonceptionaleleelevilor de 8 ani din scolile britanice

- http://www.hotnews.ro/stiri-international-5952156-elevii-din-mareabritanie-sunt-indemnati-aiba-orgasm.htm

- http://saccsiv.wordpress.com/2009/11/18/campanie-pro-masturbare-inspania-placerea-sta-in-mainile-tale/

- http://invataturicrestine1.blogspot.ro/2012/10/pericolele-modului-deeducatie-sexuala.html 